\title{
Fetal breathing movements and other tests of fetal wellbeing: a comparative evaluation
}

\author{
B J TRUDINGER, Y B GORDON, J G GRUDZINSKAS, M G R HULL, P J LEWIS \\ MARIE E LOZANA ARRANS
}

British Medical fournal, 1979, 2, 577-579

\section{Summary and conclusions}

Sixty pregnant women whose fetuses were considered to be at high risk were intensively studied with fetal and placental function tests. Fetal breathing movements were studied with real-time ultrasound and the amount of time spent breathing and the variability of the breath-tobreath interval were measured. A reduction in the amount of time the fetus spent making breathing movements and decreased variability were indicative of fetal compromise. When these results were compared with those of other tests of fetal wellbeing measurement of fetal breathing movements and ultrasound assessment of growth were more sensitive tests of fetal wellbeing than the biochemical measures (urinary oestrogen, human placental lactogen, pregnancy-specific $\beta-1-$ glycoprotein, and unconjugated oestriol concentrations) or fetal heart rate. The predictive value was highest with serum unconjugated oestriol but the results of other tests were similar.

Study of fetal breathing movements or an ultrasonic assessment of growth may provide a better screening test for fetal compromise than biochemical estimations.

\section{Introduction}

A method of accurately assessing fetal health in late pregnancy is needed to detect the compromised fetus, monitor response to treatment, and assess the risk to benefit ratio of elective preterm delivery. Many fetal and placental function tests have been devised, but none is entirely satisfactory.

Fetal breathing activity has been suggested to be a sensitive indicator of fetal health. ${ }^{1}$ Fetal breathing movements in late pregnancy reflect the functional development of the fetal central nervous system ${ }^{2}$ and its reactivity to various metabolic and sensory stimuli. In the fetal lamb terminal patterns of breathing movements have been described. ${ }^{3}{ }^{4}$ The relation between these observations and patterns of breathing movements of the human fetus is uncertain. Methodological problems limited the clinical application of early human observations with A-Scan

\footnotetext{
Institute of Obstetrics and Gynaecology, Queen Charlottes Maternity Hospital, London W6 OXG

B J TRUDINGER, MRCOG (now senior lecturer in obstetrics and gynaecology, Westmead Hospital, Westmead, NSW 2145, Australia)

$P$ J LEWIS, MD, MRCP, senior lecturer in clinical pharmacology

Department of Reproductive Physiology, St Bartholomew's Hospital Medical College, London EC1A 7BE

Y B GORDON, MD, MRCOG, lecturer

J G GRUDZINSKAS, MRCOG, research fellow

Department of Obstetrics and Gynaecology, Bristol Maternity Hospital, Bristol BS2 8EG

M G R HULL, MRCOG, consultant senior lecturer

MARIE E LOZANO ARRANS, BSC,
}

ultrasound. ${ }^{5}$ Now with real-time ultrasound direct visualisation of the fetal chest wall movements is possible, and recent studies indicate that measurement of the amount of fetal breathing ${ }^{6}$ ? and the regularity of the rate of breathing ${ }^{8}$ provides an index of fetal wellbeing as assessed by fetal outcome. We evaluated the use of fetal breathing movements as a fetal function test against other fetal diagnostic tests used to assess wellbeing in late pregnancy.

\section{Patients and methods}

Sixty patients were studied. This was a consecutive series of inpatients studied within 14 (mean 5.3) days of delivery. Studies were performed because the fetus was considered to be at high risk: 31 of the pregnant women had hypertension, 20 suspected fetal growth retardation, 2 antepartum haemorrhage, 3 a previous stillbirth, 1 diabetes mellitus, and 3 other conditions. All pregnancies were beyond 33 weeks when studied. The clinician was aware only of the results of urinary oestrogen assays and ultrasound growth measurements.

\section{FETAL BREATHING MOVEMENTS}

All patients were studied 30 to 45 minutes after a $50-\mathrm{g}$ oral glucose load. ${ }^{10}$ Our method of observation with real-time ultrasound and our analysis have been reported. ${ }^{6}{ }^{9}$ The study lasted 30 minutes. The fetus was said to be breathing when one breath followed another with an interval of less than six seconds. The fetal breathing index (FBI) was the percentage of the time that fetal breathing movements were present and thus expressed the amount of breathing. The coefficient of variation (C of $\mathrm{V}$ ) of the breath-to-breath interval (standard deviation/mean $\times 100$ ) while the fetus was making breathing movements was the index used to express variability of this activity. When these values were less than the normal fifth centile values (FBI $<32 \%$; $\mathrm{C}$ of $\mathrm{V}<36 \%$ ) for fetuses of 34 to 38 weeks' gestation ${ }^{8}$ we considered them to be abnormal. Either amount only or both amount and variability were used to evaluate fetal breathing movements. Variability was studied in only those fetuses with a normal FBI (sufficient breathto-breath intervals to analyse). A reduced variability was not classified as abnormal in fetuses past 38 weeks because in recent studies we have seen more regular breathing before labour.

\section{FETAL DIAGNOSTIC TESTS}

The concentrations of human placental lactogen (HPL), pregnancyspecific $\beta$-1-glycoprotein $\left(\mathrm{SP}_{1}\right)$, and unconjugated oestriol $\left(\mathrm{E}_{3}\right)$ were measured by radioimmunoassay ${ }^{11} 12$ on blood collected before each study of fetal breathing movements. A reading was considered to be low if it was less than the 10th centile value for a normal pregnancy of the same maturity. Each of these assays was not performed on one patient.

Twenty-four hour urinary total oestrogen assays were performed at least twice weekly. The value was considered to be low if there were at least two readings in the two weeks before delivery below our laboratory's 10th centile value. In three patients these studies were not carried out.

In 44 of the 60 patients non-stressed antenatal fetal heart rate (FHR) monitoring had been performed. A reactive trace was regarded as normal. A non-reactive trace was defined as one in which the FHR acceleration in response to movement was less than 15 beats and shortterm (baseline) variability was less than five beats. ${ }^{13} 14$

Ultrasound growth studies were performed on 59 patients. Forty- 
nine patients were examined in the first 24 weeks of pregnancy to confirm maturity, and at least two readings were taken two weeks apart in the last four weeks of pregnancy, from which fetal growth was assessed. The abdominal circumference ${ }^{15}$ was the measurement used and failure of increase over two weeks was defined as cessation of growth. In the 10 patients without complete studies a reading below the fifth centile value in the last two weeks of pregnancy was regarded as abnormal.

ANALYSIS

The various tests of fetal wellbeing were correlated with the outcome of pregnancy. To evaluate each test the sensitivity (proportion of compromised fetuses giving an abnormal result), predictive value (the likelihood of compromise if the result is abnormal), and specificity (the proportion of normal fetuses giving a normal result) were calculated. ${ }^{16} 17$ The false-positive $(\beta=1-$ specificity) and falsenegative ( $\alpha=1-$ sensitivity) errors were combined to express the Youdens index: $J=1-(\alpha+\beta) .^{18}$ This was used to express the diagnostic value of each test.

\section{Results}

The results of the study of fetal breathing movements were used to divide the fetuses studied into three groups-those with a normal amount and variability of fetal breathing, those with a normal amount and reduced variability, and those with a reduced amount. The fetal outcome for each of these groups is shown in table I. Other fetal diagnostic tests were classified as normal or abnormal and the fetal outcome recorded (table II) for each result.

Fetal compromise was considered to be present if there was perinatal mortality or morbidity, or the birth weight was less than the fifth centile for gestational age. This limit was used rather than the 10 th centile because infants with birth weights between the fifth and 10th centile had little other perinatal morbidity and fetal diagnostic test results were normal. Perinatal morbidity included fetal distress in

TABLE I-Results of fetal breathing movement studies classified by amount $(F B I)$ and variability $(C$ of $V$ ) of breath-to-breath interval in relation to fetal outcome

\begin{tabular}{|c|c|c|c|c|}
\hline \multirow[b]{2}{*}{ Pregnancy outcome } & \multirow[b]{2}{*}{$\begin{array}{c}\text { No of } \\
\text { patients }\end{array}$} & \multicolumn{3}{|c|}{ Fetal breathing movement } \\
\hline & & $\begin{array}{c}\text { Normal } \\
\text { FBI } \geqslant 32 ; \\
C \text { of } V \geqslant 36\end{array}$ & $\begin{array}{c}\text { Reduced } \\
\text { variability } \\
\text { FBI } \geqslant 32 ; \\
C \text { of } V \leqslant 36\end{array}$ & $\begin{array}{l}\text { Reduced } \\
\text { amount } \\
\text { FBI } \leqslant 32\end{array}$ \\
\hline $\begin{array}{l}\text { All patients } \\
\text { Perinatal death } \\
\text { Perinatal morbidity: } \\
\text { Fetal distress in labour }\end{array}$ & $10^{60} 11$ & $\begin{array}{r}30 \\
0 \\
5\end{array}$ & $\begin{array}{r}8 \\
0 \\
2 \\
1\end{array}$ & $\begin{array}{r}22 \\
1 \\
5\end{array}$ \\
\hline $\begin{array}{r}\text { Apgar score: } \\
1 \text { min }<4 \\
5 \text { min }<7\end{array}$ & $\begin{array}{l}3 \\
2\end{array}$ & $\begin{array}{l}1 \\
1\end{array}$ & $\begin{array}{l}1 \\
0\end{array}$ & $\begin{array}{l}1 \\
1\end{array}$ \\
\hline $\begin{array}{l}\text { Birth weight: } \\
\text { < 5th centile } \\
\text { 5th-10th centile } \\
\text { Good fetal outcome } \\
\text { Fetal compromise }\end{array}$ & $\begin{array}{l}16 \\
10 \\
35 \\
25\end{array}$ & $\begin{array}{r}1 \\
5 \\
24 \\
6\end{array}$ & $\begin{array}{l}4 \\
2 \\
3 \\
5\end{array}$ & $\begin{array}{r}11 \\
3 \\
8 \\
14\end{array}$ \\
\hline
\end{tabular}

labour (abnormal FHR in response to uterine contractions or an acidotic ( $\mathrm{pH}<7 \cdot 20$ ) fetal scalp blood sample necessitating delivery) and a low Apgar score at one minute $(\leqslant 4)$ or five minutes $(<7)$. Fifteen patients were delivered by caesarean section and in five the primary indication was suspected fetal growth retardation. In all these cases the birth weight was below the fifth centile.

Each test of antenatal fetal wellbeing was evaluated in terms of sensitivity, predictive value, and specificity (table III). The sensitivity of the biochemical tests was similar, although the assay of human

TABLE III-Evaluation of fetal diagnostic tests in assessing good fetal outcome or fetal compromise

\begin{tabular}{|c|c|c|c|c|c|c|}
\hline \multirow[t]{2}{*}{ Fetal diagnostic tests } & \multicolumn{2}{|c|}{$\begin{array}{l}\text { Sensitivity } \\
\text { TP/TP + FN }\end{array}$} & \multicolumn{2}{|c|}{$\begin{array}{l}\text { Predictive value } \\
\text { TP/TP + FP }\end{array}$} & \multicolumn{2}{|c|}{$\begin{array}{c}\text { Specificity } \\
\text { TN/FP + TN }\end{array}$} \\
\hline & No & $\%$ & No & $\%$ & No & $\%$ \\
\hline $\begin{array}{l}\text { Fetal breathing studies: } \\
\text { Amount only } \\
\text { Amount + variability } \\
\text { Ultrasound growth* }\end{array}$ & $\begin{array}{r}14 / 25 \\
19 / 25 \\
11 / 17 \\
(17 / 24\end{array}$ & $\begin{array}{l}56 \\
76 \\
65 \\
71)\end{array}$ & $\begin{array}{r}14 / 22 \\
19 / 30 \\
11 / 19 \\
(17 / 25\end{array}$ & $\begin{array}{l}64 \\
63 \\
61 \\
68)\end{array}$ & $\begin{array}{r}27 / 35 \\
24 / 35 \\
25 / 32 \\
(27 / 35\end{array}$ & $\begin{array}{l}77 \\
69 \\
78 \\
77)\end{array}$ \\
\hline $\begin{array}{l}\text { FHR monitoring } \\
\text { (non-stressed) } \\
\text { 24-h urinary oestrogen } \\
\text { Serum unconjugated } E_{3} \\
\text { Serum HPL } \\
{\text { Serum } \text { SP }_{1}}\end{array}$ & $\begin{array}{r}6 / 18 \\
7 / 24 \\
5 / 24 \\
10 / 24 \\
6 / 25\end{array}$ & $\begin{array}{l}33 \\
29 \\
21 \\
42 \\
24\end{array}$ & $\begin{array}{c}6 / 9 \\
7 / 11 \\
5 / 6 \\
10 / 14 \\
6 / 11\end{array}$ & $\begin{array}{l}67 \\
64 \\
83 \\
71 \\
55\end{array}$ & $\begin{array}{l}23 / 26 \\
29 / 33 \\
34 / 35 \\
31 / 35 \\
29 / 34\end{array}$ & $\begin{array}{l}88 \\
88 \\
97 \\
89 \\
85\end{array}$ \\
\hline
\end{tabular}

*Figures in parentheses include additional cases where single ultrasound abdomina girth measurement was normal or less than fifth centile value but serial studies were not available. negative.

placental lactogen was most sensitive. The FHR also yielded a similar result, but both the amount and variability of fetal breathing and ultrasound measurement of fetal growth provided a better index than any of these. Measuring fetal breathing in terms of both amount and variability provided a more sensitive index than measuring only the amount. There was no significant difference between the predictive values of the various tests of fetal wellbeing, although serum unconjugated oestriol provided the best index. The specificity of the

TABLE IV-Youden's index of each fetal diagnostic test

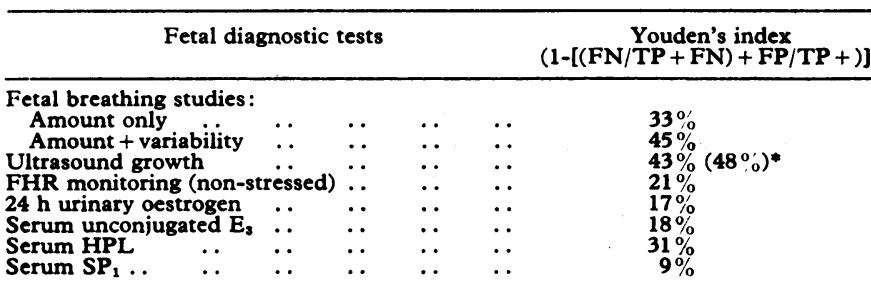

-Includes those cases where a single ultrasound abdominal growth measurement was normal or less than the fifth centile value but serial studies were not available.
TP $=$ True positive. $T N=$ True negative. FP $=$ False positive. FN= False negative.

TABLE II-Results of antenatal fetal diagnostic tests distributed according to fetal outcome

\begin{tabular}{|c|c|c|c|c|c|c|c|c|c|c|c|c|c|}
\hline \multirow{2}{*}{ Outcome of pregnancy } & \multirow{2}{*}{$\begin{array}{c}\text { No of } \\
\text { patients }\end{array}$} & \multicolumn{2}{|c|}{$\begin{array}{l}\text { 24-h urinary } \\
\text { oestrogen }\end{array}$} & \multicolumn{2}{|c|}{$\begin{array}{c}\text { Serum } \\
\text { unconjugated EI }\end{array}$} & \multicolumn{2}{|c|}{$\begin{array}{l}\text { Serum } \\
\text { HPL }\end{array}$} & \multicolumn{2}{|c|}{$\underset{\text { SPI }}{\text { Serum }}$} & \multicolumn{2}{|c|}{$\begin{array}{l}\text { Growth on } \\
\text { ultrasound* }\end{array}$} & \multicolumn{2}{|c|}{$\begin{array}{c}\text { FHR } \\
\text { monitoring }\end{array}$} \\
\hline & & Normal & Low & Normal & Low & Normal & Low & Normal & Low & Normal & Ceased & Reactive & $\begin{array}{l}\text { Non- } \\
\text { reactive }\end{array}$ \\
\hline $\begin{array}{l}\text { All patients } \\
\text { Perinatal deaths } \\
\text { Perinatal morbidity: } \\
\text { Fetal distress in labour }\end{array}$ & $10^{60} 12$ & $\begin{array}{r}46 \\
0 \\
9\end{array}$ & $3^{11} \begin{array}{r}1 \\
3\end{array}$ & $\begin{array}{r}54 \\
0 \\
8\end{array}$ & $\begin{array}{l}5 \\
1 \\
3\end{array}$ & $\begin{array}{r}45 \\
0 \\
10 \\
8\end{array}$ & $\begin{array}{r}14 \\
1 \\
1\end{array}$ & $\begin{array}{r}49 \\
1 \\
9\end{array}$ & $\begin{array}{r}10 \\
0 \\
2\end{array}$ & $\begin{array}{c}31(3) \\
0 \\
3(1) \\
2(1)\end{array}$ & $\begin{array}{r}18(7) \\
1 \\
3(4) \\
3(3)\end{array}$ & $\begin{array}{r}35 \\
0 \\
4 \\
4\end{array}$ & $2^{9}{ }^{9}$ \\
\hline $\begin{array}{l}\text { Apgar score: } \\
1 \mathrm{~min} \leqslant 4 \\
5 \mathrm{~min}<7\end{array}$ & $\begin{array}{l}3 \\
2\end{array}$ & $\begin{array}{l}2 \\
1\end{array}$ & $\begin{array}{l}1 \\
1\end{array}$ & $\begin{array}{l}2 \\
1\end{array}$ & $\begin{array}{l}0 \\
0\end{array}$ & $\begin{array}{l}1 \\
1\end{array}$ & $\begin{array}{l}1 \\
0\end{array}$ & $\begin{array}{l}3 \\
2\end{array}$ & $\begin{array}{l}0 \\
0\end{array}$ & $\begin{array}{l}1 \\
0\end{array}$ & $\begin{array}{l}2 \\
0\end{array}(1)$ & $\begin{array}{l}\mathbf{0} \\
\mathbf{0}\end{array}$ & $\begin{array}{l}\mathbf{0} \\
\mathbf{0}\end{array}$ \\
\hline $\begin{array}{l}\text { Birth weight: } \\
<5 \text { centile } \\
\text { 5th-10th centile } \\
\text { Good fetal outcome } \\
\text { Fetal compromise }\end{array}$ & $\begin{array}{l}16 \\
10 \\
35 \\
25\end{array}$ & $\begin{array}{l}10 \\
10 \\
29 \\
17\end{array}$ & $\begin{array}{l}5 \\
0 \\
4 \\
7\end{array}$ & $\begin{array}{r}13 \\
9 \\
34 \\
19\end{array}$ & $\begin{array}{l}2 \\
1 \\
1 \\
5\end{array}$ & $\begin{array}{r}7 \\
8 \\
31 \\
14\end{array}$ & $\begin{array}{r}8 \\
2 \\
4 \\
10\end{array}$ & $\begin{array}{r}11 \\
7 \\
29 \\
19\end{array}$ & $\begin{array}{l}5 \\
3 \\
5 \\
6\end{array}$ & $\begin{array}{r}4(1) \\
8 \\
25(2) \\
6(1)\end{array}$ & $\begin{array}{r}8(3) \\
1 \\
7(1) \\
11(6)\end{array}$ & $\begin{array}{r}9 \\
5 \\
23 \\
12\end{array}$ & $\begin{array}{l}4 \\
2 \\
3 \\
6\end{array}$ \\
\hline
\end{tabular}
*Figures in parentheses represent additional cases where a single ultrasound abdominal girth measurement was normal or less than the fifth centile value but serial studies 
ultrasound studies of fetal growth and fetal breathing movements was lower than that of the biochemical studies.

The values of Youden's index, in which the false-positive and falsenegative errors are combined and subtracted from $100 \%$ are shown in table IV. Ultrasound assessment of growth and fetal breathing movements had the largest values.

The results of the study of fetal breathing movements were compared with the abnormal results of the other fetal diagnostic tests combined. Of the 25 patients with fetal compromise, $19(76 \%)$ had abnormal fetal breathing movements and $22(88 \%)$ an abnormality on at least one of the other fetal diagnostic tests. Both of these proportions were significantly greater $(P<0.001)$ than the proportion of patients with a good fetal outcome who had positive results $(31 \%$ and $46 \%$ respectively). Among the 30 patients in whom fetal breathing movements were considered abnormal in either amount or variability, 24 $(80 \%)$ had at least one other abnormal fetal diagnostic value compared with only $14\left(47^{\circ}\right)$ of the 30 patients with normal fetal breathing movements $(\mathbf{P}<0.01)$. Abnormal fetal breathing movements therefore occurred among patients in whom other indices of fetal wellbeing were abnormal and both selected the compromised fetus.

\section{Discussion}

Human fetal breathing movements provide an index of fetal wellbeing. In our study of fetuses considered to be at high risk our results confirm that the amount of time during which breathing movements are present provides a useful index of fetal health. ${ }^{6} 7$ The value of these studies can be improved by considering also the variability of the breath-to-breath interval. We have shown that a pattern of more regular breathing movements indicates fetal compromise among the high-risk group. This pattern is seen in fetuses subsequently born small for gestational age. ${ }^{8}$ In other studies of patterns of fetal breathing movements in normal pregnancy we have noticed that the variability of the breath-to-breath interval diminishes in the last weeks of pregnancy, and its earlier occurrence in fetal compromise may be explained by accelerated maturation. A similar observation has been reported in the fetal lamb. ${ }^{10}$ Abnormal fetal breathing movements selected not only the compromised fetus but also those fetuses with abnormal values of other tests of wellbeing. This confirms its validity as a measure of fetal health.

The comparative analysis of methods of assessing fetal wellbeing showed that the ultrasound studies are the most sensitive. Ultrasound measurement of fetal abdominal girth ${ }^{29}$ to assess fetal body size is more discriminating than cephalometry in detecting fetal growth retardation in association with placental insufficiency. ${ }^{21}$ Fetal breathing movements provide an index as sensitive as the ultrasound assessment of growth. Ultrasound studies are more difficult to offer to a large population, yet the better selection achieved by them may justify the cost.

We have shown that these methods of fetal assessment provide a better screening test for fetal compromise than the biochemical tests in current use. Human placental lactogen measurements provided the best biochemical index. Application of this test to a non-selected population ${ }^{22}$ yields a higher sensitivity, which may be explained partly by the preponderance of the patients with good fetal outcome. In that series higher values of HPL than our 10th centile levels were used to distinguish the fetal outcome groups. Urinary oestriol excretion has been studied in a similar manner. ${ }^{23}$ The results of $\mathrm{SP}_{1}$ were disappointing and would indicate no apparent advantages in the use of these "newer" placental proteins. ${ }^{24}$ Antenatal nonstressed FHR monitoring provided poor selectivity and our results in this group confirm the need to monitor FHR during contractions. ${ }^{25}$

The lack of any significant variation in the predictive value of the fetal diagnostic tests was an unexpected finding. It may be argued that those fetuses selected by the less sensitive measures are the most seriously compromised. Nevertheless, the similar predictive values of all the fetal diagnostic tests indicates an equal proportion of morbidity among the positive results. Serum unconjugated oestriol was associated with the highest predictive value and may indicate highest risk. The lower specificity of the fetal breathing movement studies was associated with a higher false-positive rate. This highlights our inability to quantify fetal and neonatal health except into rather coarse categories of morbidity. By comparison, the lower sensitivity and greater specificity of the biochemical tests were associated with an increased false-negative rate, an error to be avoided in a screening test. None the less, the high specificity of all the fetal function tests emphasises their importance in confirming continuing fetal health in those patients considered to be at high risk as well as in predicting compromise.

The false-positive error (1-specificity) and false-negative error (1-sensitivity) are combined and given equal importance in calculating Youden's index. This adjusts for an increased sensitivity at the cost of reduced specificity. Fetal breathing movements and ultrasound assessment of growth have the greatest diagnostic value. HPL assay is the best biochemical index. The cut-off points for the diagnostic tests used were based on ranges previously defined in normal subjects and in current clinical use. The false-positive and false-negative errors reflected in specificity and sensitivity represent clinical application of the various diagnostic tests to a high-risk group.

In this study we have evaluated the various methods of fetal assessment for predicting fetal compromise. We have not tried to determine the clinical role of these methods of assessment in monitoring antenatal fetal progress and indicating an "action point" for delivery. A comparative analysis of serial studies will be necessary to determine this.

Requests for reprints to: Dr B J Trudinger, Department of Obstetrics and Gynaecology, Parramatta Hospitals, Westmead Centre, Westmead, NSW 2145, Australia.

\section{References}

${ }^{1}$ Boddy, K, and Dawes, G S, British Medical Bulletin, 1975, 31, 3.

2 Fox, H E, et al, American Journal of Obstetrics and Gynecology, 1978, 132,

354.
3 Patrick, J E, Dalton, K J, and Dawes, G S, American Fournal of Obstetrics and Gynecology, 1976, 125, 73.

4 Chapman, R L K, et al, American fournal of Obstetrics and Gynecology, 1978, 131, 894.

${ }^{5}$ Dawes, G S, American Review of Respiratory Disease, 1977, 115, 5.

Trudinger, B J, et al, British Fournal of Obstetrics and Gynaecology, 1978, 85,662 .

${ }^{7}$ Platt, L D, et al, American Journal of Obstetrics and Gynecology, 1978, 132, 514.

${ }^{8}$ Trudinger, B J, Lewis, P J, and Pettit, B, British fournal of Obstetrics and Gynaecology. In press.

${ }^{9}$ Lewis, P J, Trudinger, B J, and Mangez, J, British fournal of Obstetrics and Gynaecology, 1978, 85, 86.

${ }^{10}$ Natale, R, Patrick, J, and Richardson, B, American fournal of Obstetrics and Gynecology, 1978, 132, 36.

11 Gordon. Y B, et al, British fournal of Obstetrics and Gynaecology, 1977, 84, 642 .

${ }^{12}$ Hull, M G R, Monro, P P, and Gillmer, M D G, British fournal of Obstetrics and Gynaecology, 1978, 85, 645 .

${ }^{13}$ Flynn, A M, and Kelly, J, British Medical fournal, 1977, 1, 936.

${ }^{14}$ Rochard, F, et al, American fournal of Obstetrics and Gynecology, 1976, 126, 699 .

15 Campbell, S, and Wilkin, D, British fournal of Obstetrics and Gynaecology, $1975,82,689$.

16 Casscells, W, Schoenberger, A, and Grayboys, T B, New England fournal of Medicine, 1978, 299, 999.

17 Gordon, Y B, et al, Lancet, 1978, 1, 1001.

18 Armitage, P, Statistical Methods in Medical Research, p 433. Oxford, Blackwell Scientific, 1971.

19 Bowes, G, et al, Proceedings of the Fifth Conference on Fetal Breathing. Nijmegen, University of Nijmegen, 1978.

${ }^{20}$ Campbell, S, in Fetal Physiology and Medicine, ed R W Beard and $\mathbf{P}$ Nathanielsz. London, Saunders, 1976.

${ }^{21}$ Vladimiroff, J W, Bloemsma, C A, and Wallenburg, H C S, American fournal of Obstetrics and Gynecology, 1978, 131, 857.

22 Letchworth, A T, Slattery, M, and Dennis, K J, Lancet, 1978, 1, 955.

${ }^{23}$ Beischer, N A, Medical fournal of Australia, 1975, 2, 379.

24 Gordon, Y B, et al, Lancet, 1977, 1, 331.

${ }_{25}$ Trudinger, B J, and Boylan, P, Obstetrics and Gynecology. In press. 